\title{
Mediated friendship: Online and offline alliances in girls' everyday lives in Italy
}

OÑati SOCiO-Legal SERIES Volume 10, ISSuE 1S (2020), 100S-115S: THE FOURTH WAVE OF

FEMINISM: FROM SOCIAL NETWORKING AND SELF-DETERMINATION TO SISTERHOOD

DOI LINK: HTTPS://DOI.ORG/10.35295/OSLS.IISL/0000-0000-0000-1085

ReCEIVED 17 JANUARY 2019, ACCEPTED 11 SEPTEMBER 2019

\section{ARIANNA MAINARDI* (iD)}

\section{Abstract}

This article engages with the current debate on feminisms and digital media by looking at the tension between individualism and collective action. Drawing on an empirical research project involving girls, carried out in Italy and focusing on female processes of subjectivation in a postfeminist new media context, it will discuss constraints and opportunities shaped by the everyday use of social media. The article places itself in the latest trend of cyberfeminist studies, by analysing friendship relationships developed among girls in and through digital media. It also looks at how the mediated nature of social network sites offers room for the building of alliances among girls, and how this challenges online and offline gender norms. In doing so, the article reflects on the way female relationships change and are reworked in digital culture, thus giving a new meaning to the feminist concept of sisterhood.

\section{Key words}

Girls; digital cultures; friendship; gender; communication

\section{Resumen}

Este artículo se ocupa del debate actual sobre feminismos y medios digitales, con una mirada a la tensión existente entre el individualismo y la acción colectiva. Partiendo de un proyecto de investigación empírica con chicas, realizado en Italia y enfocado en los procesos femeninos de subjetivación en un contexto posfeminista de nuevos medios, el artículo trata sobre las limitaciones y las oportunidades modeladas por el uso cotidiano de medios sociales. El artículo se sitúa en la reciente ola de estudios ciberfeministas, analizando las relaciones de amistad entre chicas a través de medios digitales. También se ocupa de cómo la naturaleza mediada de las redes sociales digitales ofrece un espacio para las alianzas entre chicas, y de cómo esto desafía las

\footnotetext{
* Arianna Mainardi is a postdoctoral research fellow at the Department of Sociology and Social Research at the University of Milano-Bicocca. Her research deals with political participation and gender issues, digital culture, youth and social change. Email address: arianna.mainardi@unimib.it
} 
normas de género en Internet y fuera de él. Al hacerlo, el artículo reflexiona sobre cómo las relaciones entre mujeres cambian y se transforman en la cultura digital, dando un nuevo significado al concepto feminista de sororidad.

Palabras clave

Chicas; culturas digitales; amistad; género; comunicación 


\section{Table of contents}

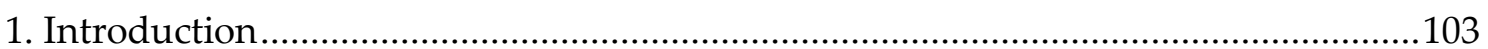

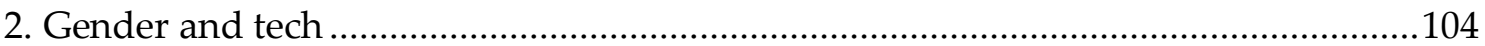

3. Doing research with girls in a postfeminist digital context .......................................106

4. Building female alliances through digital media.....................................................107

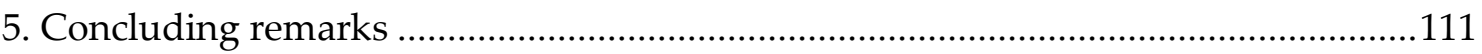

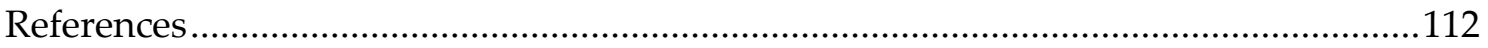




\section{Introduction}

This article aims to contribute to the current debate on feminisms and digital media by looking at the tension between individual and collective action of girls in a postfeminist digital media context. The debate is rich and controversial, crossing different fields and disciplines. The article addresses this issue by exploring the margins in, and through which, processes of subjectivation take place in the mediated experience of social media. In order to understand the relationship between individual and collective action, throughout the article I will question the borders between political and non-political, online and offline, private and public experiences; in doing so, the article challenges certain implicit, dichotomous categorisations that come to the surface when entering the realm of digital culture.

Drawing on an empirical research project involving girls between 16 and 19 years old, carried out in Italy and focusing on female processes of subjectivation in a postfeminist new media context, I will discuss the constraints and opportunities shaped by the everyday use of social media. Friendship is a vital element in these processes, and from a sociological perspective it has been defined as crucial site where people give meaning to their worlds in the everyday experience of intimate life (Blatterer 2015, Blatterer and Magaraggia 2016). ${ }^{1}$ Throughout the interviews conducted for this project, friendship emerges as a central site in, and through which, girls negotiate their subjectivities in an online and offline context. Girls' life in the context of a social network site is strongly regulated by peer culture. Thus, while peer culture on Facebook is often characterised by a normative vision of gender, sexuality and relations (Ringrose 2011, Ringrose et al. 2013), girls' online and offline friendships, by contrast, open up different spaces of sharing and caring. In fact, the interviewees promptly brought attention to friendship relationships with other girls. By analysing the gender representations that the interviewees shared online, I observed how online and offline interactions with the peer group strongly influenced digital practices on social network sites. ${ }^{2}$ The peer group usually exercises a regulatory function that inhibits those expressions of femininity that distance themselves from the dominant canons. In particular, female relationships are subject to specific tensions, which are the result of the constant normative presence of the male gaze. The friendship relationships between girls as mediated by digital technologies, however, create an ambivalent space that is not always determined by the coercive presence of boys, and therefore require a more in-depth analysis.

The article focuses on the relationship between digital media and gender relations, on the one hand, thus considering how the boundaries between agency and market-driven formations of the self are becoming more blurred; on the other hand, it provides evidence for the unprecedented possibilities offered by the access to Internet, online content production and content sharing (Gajjala and Oh 2012). Considering this ambivalence, the article responds to the need to focus on the issue of agency and choice in a postfeminist new media context, taking as its starting point the experiences of the subjects involved in those tensions. The article thus contributes to the current debate about, and analysis of, new forms of political participation among youth (Alteri et al.

\footnotetext{
1 Data was drawn from a doctoral research project carried out at the University of Milano-Bicocca, which was completed in 2015.

2 Parts of the research are discussed in Mainardi 2018.
} 
2017). It does so by unravelling the tension between the drive towards individualism, and a new space of subjectivation that is constitutive of the gendered experiences of girls in an online and offline context.

In the first part of the article I will shortly analyse the ambivalent relationship between gender and technology, showing both the opportunities and constraints inherent in this nexus. Next, I will discuss the postfeminist debate that addresses the issue of neoliberalism and subjectivity in the context of youth digital culture, and its consequences for empirical research. Finally, drawing on my empirical data I will analyse friendship relationships developed among girls in and through digital media, looking at how the mediated nature of social network sites offers room for the building of alliances among girls, and how this challenges online and offline gender norms.

\section{Gender and tech}

Studies on gender and technologies highlight the ambivalence inherent in this relation, where inequalities are produced and reproduced, along with the creation of new spaces of subjectivation, political discourse and action. Technologies are not neutral; on the contrary, we should think of technologies as social constructions that can crystallise different forms of dominations (e.g., gender, class, race, ability), and contribute to the definition of social roles (Wajcman 2009). Feminist researchers have highlighted that gender and technologies shape each other, producing and reproducing different forms of power. Indeed, social relationships and the economic/political contexts that create these technologies are based on gendered relationships; technologies become part of the construction of gender relations, and it is not possible to understand technologies without referring to gender (Cockburn and Ormrod 1993).

On the one hand, the Internet and digital media contribute to the reproduction of gender inequalities by limiting Internet access and technological usages, for example, and as a result of different levels of digital capacities (Bracciale 2010). Also, the digital environment reproduces those gender orders that characterise offline life. Misogyny, sexism and heteropatriarchy resurface online (on a different level, that is, as artefact, in practices and in culture), creating an environment that often risks excluding LGBTQ people and women (Pavan and Mainardi 2019).

On the other hand, technologies are also a space of empowerment and experimentation. For instance, in the early 1990s, cyberfeminist scholars (Wilding 1998) argued that the Internet implied the possibility of experimenting with different forms of sexuality. They discussed the boundaries of gender identity by constructing paths of subjectification through the use of the network (the insistence on the term network corresponds with a vision of the Internet as an alliance space and community construction). The possibility of building disincarnated relationships through new media has been considered a potential liberation, because it allows people to escape the limits of the body as defined by the material world, and to escape and transgress daily life. In doing so, users can overcome the social bonds that are reinforced by discourses of race, age and gender, and find legitimacy in the characteristics of offline bodies; in the absence of a risk of physical aggression, they can also express their subjectivities.

Moreover, young female, underground groups have started making political use of the Internet. As Anita Harris (2008) has stated, online culture has been the stage of new 
forms of political participation and engagement in the realm of girl culture. Looking at the riot grrrl movement, an underground, young and radical feminist movement that emerged in the early 1990s, from the merging of punk subculture and feminist politics, Harris shows the potentialities of the Internet for alternative media cultures (e.g., through e-zines, online diaries, blogs, listservs, discussion groups and personal pages) as a tool for counter expression. Also, the Internet has served as a space of political confrontation and circulation of political messages that challenge the patriarchal order, and for the dissemination of less stereotypical imaginaries of gender and sexuality: a weapon in the hands of young women, who could thus access a new space of expression outside the male-dominated public space.

Starting from the experience of the riot grrrl movement, some studies have focused on the political and transgressive uses of the Internet by young women (Harris 2008); others have chosen to question the panorama of new media in the postfeminist context, looking at how "common" girls can negotiate a space of participation and expression through the web (Banet-Weiser 2011, Dobson 2015). However, Internet and digital media have changed along with the practices associated with them. Firstly, the number of connected people has grown considerably, thanks also to the increasing diffusion of mobile technologies. The Internet, as we experience it today, allows unprecedented network constructions and direct access to mass media, which did not exist before. Moreover, the distinction between "virtual" and "real" - an ideal categorisation for the understanding of Internet challenges to social and political transformation - is out of date. Instead of the notion of "virtual" we now use the term "online", to indicate how being connected is nowadays a crucial dimension of experience. In this sense, the use of digital media becomes a space of self-expression closely connected to the materiality of offline existence - thus producing new gender regimes and different spaces of resistance (Mazzarella 2010, Ringrose and Barajas 2011, Ringrose et al. 2013).

These configurations of digital practices have had relevant consequences for both individual and collective experiences, in terms of identity expression, political participation and social engagement. Studies about the Internet and everyday life have shown how - with the new configuration of online and offline experiences, fostered by the fluid use of mobile devices and the widespread dissemination of social network sites - the barriers between private and public have dramatically changed, along with the meaning we associate with the private and public sphere. Furthermore, studies on social movements have questioned the consequences of the use of ICTs - Information Communication Technologies - for changes in social and political life, by looking at the dynamics of collective action (Earl et al. 2015); they have, for instance, invited scholars to explore new frames through which to interpret mediated political practices of social movements (Mattoni and Treré 2014), or studied the specific dynamics of online collective action (Pavan 2017).

As a consequence, some scholars have come to see the Internet, and ICTs, as one of the main characteristics of a fourth wave of feminism, linked to new forms of activism such as \#activism and online campaigns, or to the possibilities of displaying numerous kinds of subjectivities. At the same time, these scholars highlight the risk of a diffusion of pop feminism, a feminism co-opted by capitalism, which instead of deconstructing the patriarchal order happily coexists with it (Baer 2016, Magaraggia and Ruspini 2017). 


\section{Doing research with girls in a postfeminist digital context}

Girls in literature are generally not represented as political actors in our society, because they are immersed in the so called "postfeminist context" (McRobbie 2009); the latter could be defined as a form of girl power made marketable, or commodified. Girls are entitled only to an individualistic process of subjectivation, and as a consequence they embody, symbolically, the perfect neoliberal subject (Tiqqun 2001). The postfeminist frame analyses precisely this contemporary interweaving of subjectivity and neoliberalism, recognising that the issue of individualism needs to be made central in the neoliberal debate as much as the feminist one, if we are to understand the new gender regime that is at play. In this regard, Angela McRobbie (2009) defines postfeminism as a double entanglement: namely, the coexistence of the acquisition of new rights in terms of gender relations and sexuality, on the one hand, and of neoconservative and neofundamentalist pressures, on the other. McRobbie (2009) points out that through the dissemination of feminist discourses (e.g., emancipation, freedom of choice, etc.), girls are actually re-positioned within rigid gender categories. The control to which girls would once have been subjected no longer occurs in the frame of obligation, but rather in one of choice (Gill 2007). A contributing factor in this process is the simultaneous incorporation, revision and depoliticisation of many of the main objectives of the second wave of feminism (Stacey 1990, 339). Hence, to describe this complex scenario McRobbie uses the definition "postfeminism." This term is partially marked by an antifeminist sentiment. In fact, she has noted that elements of feminism previously included and incorporated into political and institutional life, on the basis of words such as "choice" and "emancipation", have subsequently been converted to a more individualistic discourse and, under this new guise, used as a kind of substitute for feminism especially in the media and in popular culture, but also in public policies (see Harris and Dobson 2015).

The issue is further complicated by a new form of relationship and visual representation that is being fostered by digital media, especially social network sites (SNS). Dobson (2015) has highlighted that the postfeminist context reproduces female representations that are expressed through rigid gender-body practices, normative codes of beauty and stylised performances of heterosexual sexuality. Moreover, she has acknowledged that this gender regime is also at play in the digital realm. Finally, the issue of the girls' use of digital media is often the object of moral panic; indeed, SNS are portrayed as spaces of individualisation and as a danger for youth, especially for girls, while the latter are portrayed as victims without agency (Cassell and Cramer 2008).

In the postfeminist imagery, postfeminism marks the end of the great collective mobilisations, and the prevalence of impulses to individualism and adherence to the logics of the market. In this article I have chosen to analyse the sphere of daily life as a strategic area, where to investigate the development of micro-resistance policies (Budgeon 2001) and negotiation strategies. In particular, I will focus on the dimension of everyday life as defined, but not determined, by the use of digital technologies and social network sites. Digital media offer new spaces of mediation, characterised by specific technological affordances through which girls build their relationships with others and acquire new resources to build their own identities. As other scholars have shown, SNS are spaces in which gender norms are reproduced; at the same time, though, 
girls are able to build online spaces of resistance and subversion, in and through which they can produce new subjectivities (Dobson 2015).

In order to avoid rhetorical discourses about girls and digital media, focusing instead on the issue of power and domination that are at play in girls' digital practices, in this article I use a girls-centred methodology (Mitchell and Reid-Walsh 2008): a research practice and a perspective that question the positionality of both researcher and researched at the crossroads between gender and age. Informed by Judith Butler (1988) and her idea of gender as performance, in particular, I have approached my fieldwork data thinking critically about the power relationships that invest everyday life. In this light I have looked at private and mundane activities as spaces of struggle, without considering the subjects of my research, namely girls, as a stable entity, but rather, as subjectivities whose agency is defined at the crossroads between different axes of power: gender, sexual orientation, class and geographical origin, to name a few. The methodological tool that I applied in my empirical research was in-depth interviews, where I considered the interview not just a moment of data collection, but a research relationship more broadly, in which both interviewer and interviewee co-constructed the knowledge around the issue being discussed. The empirical research involved 32 girls coming from different socio-economic contexts, and the interviews have been interpreted following a discourse analysis approach. The article focuses on the narratives through which the girls discussed their relationship with close female friends.

This methodological approach has helped me recognise online and offline practices through which the girls deal with the everyday structure in which they are immersed. It has also been valuable to uncover the "political" dimension of these practices, as when girls actively create a safe space online through which to perform their identity more freely, for example by creatively using anonymity in order to play with sexualities in online spaces. However, these practices are also political, in the way they challenge the heteronormative dynamics that mostly characterise social network sites, for instance when posting online a picture of a female kiss between friends, and then ignoring adults' comments and judgment (see Mainardi 2018). My opinion is that what emerges from the narratives of girls can be considered real micro-practices of resistance, or small survival practices (Budgeon 2001), which open up new areas of subjectivation. However, these are often individual practices, which struggle to find confirmation within the peer group and remain far from collective resistance action. At the same time, girls interact in and through digital media not just on their own but also with their female friends; the final section will focus on these collective, micro-practices of resistance.

\section{Building female alliances through digital media}

Let us now see how female friendships that are mediated by the Internet can become an instrument of survival, in the complex terrain of the heteronormative culture of the Italian context (Zappino 2016), where a double standard between girls' and boys' sexualities is still strong, with consequences on girls' possibilities of self-determination. As Hajek (2018) points out, the Italian context is bound by a public debate that aims to gain control over girls' and women's use of their bodies and sexualities: in this context, who transgresses "social roles and norms about sexuality" (Hajek 2018, 139) is sanctioned. At the same time, there is a proliferation of discourses of freedom and choice 
that risk making feminist claims out of date, individualising girls' reflexivity and at the same time covering contemporary forms of male domination (Hajek 2018).

Against this background, friendship remains an important space for girls to build their position as subjects - no longer alone in dealing with postfeminist culture and with role models that are not very sustainable. The analysis of the interviews allowed me to identify a substantial number of experiences in which girls use digital technologies with their closest friends. The digital practices I analysed here are as follows: commenting on Facebook with friends, discussing the images to be published and open "collective" profiles on social network sites.

The paper focuses mainly on Facebook interactions, because at the time of the interviews it was still the most used social medium among the girls. This analysis could therefore be able to give important indications about a crucial relational space of the girls' peer culture. Some relational mechanisms and gender repertoires can be considered indicative of girls' everyday social media interactions more broadly speaking, though at the same time I am aware that different online spaces have different affordances as well as different cultures. For example, the conducted research highlighted how Instagram, and other social media, can be experienced as less normative - given, for example, that there is less adult presence and that a certain degree of anonymity is possible - and is therefore sought after by girls, in that they feel freer in the expression of the self. Precisely in order to highlight this tension, in which the girls actively negotiate spaces for themselves online, even the less obvious ones (like a porn site), at the end of this article I will analyse an episode that occurred outside of Facebook.

If we focus on the interactions that occur in and through social network sites like Facebook, which are strictly linked to girls' offline experience, such as the school setting, we notice that a recurring practice is to integrate the use of SNS into the normal flow of conversation between friends, in different physical spaces (such as a school or a park). It is indeed common for girls to read and comment on the profiles of other female and male friends when they are together.

Or maybe when we talk about someone I do not know (...) I look for them on Facebook, while she says (...) I do not know (...) she (my friend) started speaking about this or that dude, then I try to see what she or he looks like. (Lucia, 16 years old)

Observing other people's profiles with friends is a common activity, and has a first, interesting implication: the girls' personal profile moves from being a "private" space for self-representation to being used in a "collective" way. Girls also break Facebook's rules about owning a single profile, one which corresponds with a "real" subject. Indeed, as van Zoonen (2013) points out, Facebook - through its policy - fosters a normative development of online identity and relationships; for instance, it also asks people to completely adhere to their "real life" characteristics by providing personal details such as name, date of birth, attended school. This standardised and regulatory practice makes Facebook a less experimental place for the girls we interviewed, compared to other social media (like Instagram). Nevertheless, girls actively negotiate SNS affordances according to their leisure/pleasure needs, and in doing so girls open up to a new understanding of online and offline interaction, along with their relational goals. In this way, even friends who do not have a personal profile on Facebook can observe and participate in the interactions that occur on the SNS. This practice inevitably strengthens girls' friendship 
relations, up to the point that they exchange the passwords of their personal profiles. It is relevant to observe that this trust practice rarely happens with boyfriends, as Lucia explains:

He [the boyfriend] doesn't know my password, he can only enter my Facebook profile when I give it to him, on the phone.

Interviewer: Does anyone know your password?

My best friend but she always forgets it. Even if it is her name (...) the password [laughs]. (Lucia, 16 years old)

As we can see, when the use that girls make of Facebook is driven by their involvement in friendships, online and offline are not separate worlds; rather, we must talk about different settings ("relational milieu") in which to hang out with the peer group. As a consequence, public and private spaces get mixed up and girls are urged to imagine new borders around friendship in the mediated context of SNS. As we have seen, on the one hand new digital environments implement offline peer interaction, while relationships open up to challenges and opportunities; on the other, they offer a new setting in and through which girls are asked to build and discuss their subjectivity with others.

Here, girls seem to engage with practices driven by friendship needs even in the most apparently individual acts: that of posting and sharing personal pictures. Also, in these circumstances the presence of friends is central to girls' online practices, even in the most private act of choosing a photo to use as a personal profile picture. The identity charge associated with the profile picture is relevant; choosing the picture that will represent girls in an online environment is often anything but a "light" gesture, one without importance. Although mobile, fluid and changing over time, the profile picture is a relevant space of expression, from where it interacts with others, and as such it is central to girls' participation in the specific online peer culture.

The interviews clearly show that the image the girls decided to adopt, in order to represent themselves online, is often the result of a reflective process. Moreover, the interviewees underlined that in this process the girls are not necessarily alone; not infrequently, friends advise them on which photos to publish. This aspect is interesting because it shows that girls, in a crucial phase of online identity building, feel the need to share their decisions with friends.

[I upload] only when they are very good, I have to love [the pictures] a lot because if they do not convince me I think they cannot convince others as well.

Interviewer: is there anyone to ask for an opinion?

My friends, my best friend, she is also the one that took the pictures, or otherwise a classmate of mine. (Linda, 15 years old)

The complicity with friends that is created in this case indicates the possible alliance between girls, which becomes a resource in the struggle to deal with the gender pressures to which digital culture exposes them. Another significant practice can be discerned in this perspective; sometimes girls take pictures with their friends and then modify them on the computer, with the aim of eventually uploading them to Facebook. In the example offered by Linda, we can witness the most classic case of this practice; girls ask their friends to take the picture that will then become the image of their profile. In Francesca's narrative, the practice of meeting with friends (sisters, in this case) in 
order to take pictures together, and then putting them on Facebook, happens first of all for fun.

I like it when we are all three at home doing nothing at the computer (...) my sister attends the artistic school and likes to take pictures, and then I say: 'let's go and take pictures to share on Facebook.' So we go down to the park and do some kind of photo shoots, we have fun, we're dressed a little weird. And then in the evening, when we get home, we modify them. We spend a lot of time changing them all, changing the colours or making them black and white, and then we put them on Facebook. (Francesca, 18 years old)

The desire to share photos on Facebook therefore activates group dynamics that allow girls to spend time together, to play with clothing and body poses. For Francesca, uploading photos to Facebook is only the final procedure in an activity that involved numerous physical spaces - the house where they got dressed, the park where they took the pictures, the room where they used the computer to edit the photos - and different technologies - the digital camera with which they took the pictures, the editing program they used to edit them, the social network site on which they shared them - through which to combine a private and public understanding of bodies and relationships. Francesca's example speaks about an experience that allows her to play and experiment with her body and her own image, both in the offline and in the online dimension.

Furthermore, girls not only build an intricate web of offline, female relationships in order to feel comfortable online and play with the forms of visibility sustained by online interaction with peers; they also inhabit digital space, holding hands with their female friends. Indeed, SNS such as Facebook, among other things, ask to make certain demographic details visible (e.g., age, sex, place of birth, etc.) as well as those connections with people with whom one is linked offline (family or sentimental ties). In this regard, by deciding to define themselves in the online context through their relationship with other girls, the interviewees strengthened female alliances and also challenged heteronormative, online culture. In some cases, girls thus decided to write on Facebook that they were "in a relationship with" their best friends. In doing so, girls are not necessarily claiming to be in a lesbian relationship, but they turn Facebook's requests to their own advantage, adapting them to their relational needs, for example by giving more importance to friendship relationships than to couple relationships, or biological family. Moreover, girls renounce - albeit in a "light" way - to accept the rules of presentation of the self as prescribed by Facebook, expanding the space of possibilities in which to build their gender and sexual identity online.

A final example of this possibility for girls to build collective process of subjectivation in the online context is that of Alessandra and Margherita, who created a male profile on a porn site by inventing a name and using a fake photo. They used this shared profile not only to watch a porn video but also, and in particular, to chat with the girls who performed in this video. Theirs can be defined as a classic case of online gender swapping (change of gender identity through an avatar), but it is especially a practice that allowed them to put their gender identity in play through the Internet. The possibility to choose and play with different identities encourages the fluidity of the expression of gender and sexuality (Butler 1988), thus allowing experiments with sexuality and gender. To play with anonymity and sexuality becomes possible thanks to friendship. 
We invented a name. Like Mario (...), I decided the name, and she decided the surname, to be balanced. We found a picture of a friend of ours who is on the other side of the world, so OK. Now we are doing this experiment to see how many girls we can meet. We have reached two that asked for friendship [laughs].

The creation of this profile offered Alessandra and Margherita the opportunity to experiment in the field of gender identity (i.e., by building a male profile) and, at the same time, to explore the boundaries of their sexuality outside the heterosexual standard. Thus Margherita and Alessandra chat mainly with girls, and watch pornographic videos uploaded by young women. The Internet offers them an area of safe experimentation also because it is anonymous. It is interesting to note how this experience acquires a particular meaning for Alessandra and Margherita, because it is not conducted individually, but in the company of a friend. Thanks to the girls' complicity it is possible to live this space on the Internet with pleasure and fun - and to use anonymity actively.

In sum, we could say that girls are not always alone when they navigate a postfeminist culture in social network sites, but that they are also often accompanied by their best friends or sisters. This implies that the relationship with friends offers girls, first of all, a survival space in which to produce self-portraits that make them feel more at ease; secondly, it allows them to have fun, and experiment, in the semi-public space of the social network site. Thirdly, the mediated nature of digital space offers room for exploration of, if not experimentation with, different gendered subjectivities.

\section{Concluding remarks}

In the context of social network sites, experimentation spaces become more nuanced, also because the references to the offline body are now constitutive of girls' digital practices. Simultaneously, forms of alliance among girls are built precisely in the need to come to terms with the new body politics and gendered visual conditions fostered by online spaces. Here, new spaces of subjectivation are possible thanks to the mediated nature of girls' friendship, where girls actively take advantage of the complex relationship between gender and technologies.

Social media constitute an indissoluble terrain in and through which girls experience and discuss their identity - here online and offline context appear strictly interrelated. The interviewees do not passively interact with digital space and its norms; on the contrary, they actively produce a situated understanding of the digital environment and of digital culture, which allows them to explore and experience with body, gender and sexuality. Girls' appropriation of SNS is a negotiation of the specific affordances of the SNS - with their limits and constraints - in order to redefine their space of expression.

By addressing the relationship between subjectivity and neoliberalism, scholars have argued that, within the neoliberal and postfeminist context, the intense process of individualisation makes it quite impossible for girls to recognise common traits, or points of contact, between their own experiences and those of other young women. Individualisation functions as a device that inhibits forms of awareness about gender inequalities, and that supports the postfeminist frame according to which a push towards individualism and a re-proposal of rigid gender norms have taken place, in a context in which every form of collective movement seems out of place. Here power acts 
not explicitly, "ordering" the subjects to behave in a certain way, but through the bodies; according to this vision, the girls' bodily practices reproduce, on a daily basis, styles and models of femininity that support the hegemonic gender cultures. Power relations thus become "invisible", permeating relationships and representations of girls.

Nevertheless, the forms of complicity that emerged from my research show that digital media could also offer a space for forms of alliance between girls. Indeed, digital technologies support the creation of a space for relationships and understanding among young women that makes online self-expression more sustainable. When girls establish relationships of mutual understanding and support, digital practices support a less stereotyped gender imaginary, as this example illustrates: "To a friend of mine it once happened that they had written 'you are ugly in this picture' (...) a boy. I told her not to care. Do you like the photo you've put? That's enough" (Miriam, 17). Moreover, outside the more normative space of Faceboook, the relationship among girls as supported by online spaces also offers the possibility to experiment and play not only with the potentials of building more open gender identities, but also with a sexuality that goes beyond the heteronormative model.

In conclusion, the outcomes of my research urge us to reflect upon the much nuanced distinction between individual and collective processes of subjectivation that occur in the digital context. In reality, the cartography of feminist subjects is complex, as well as the possible forms of action in the digital realm; new spaces of subjectivation can emerge in the interstices, in offline relationships, in the margins, in new relationships created in and through online spaces, in the redefinition of alliances between individual and collective life in online and offline spaces.

\section{References}

Alteri, L., Leccardi, C., and Raffini, L., 2017, Youth and the Reinvention of Politics. New Forms of Participation in the Age of Individualization and

Presentification. Partecipazione e Conflitto [online], 9(3), 717-747. Available from: https://doi.org/10.1285/i20356609v9i3p717 [Accessed 12 September 2019].

Baer, H., 2016, Redoing feminism: digital activism, body politics, and neoliberalism. Feminist Media Studies [online], 16(1), 17-34. Available from: http://doi.org/10.1080/14680777.2015.1093070 [Accessed 12 September 2019].

Banet-Weiser, S., 2011, Branding the Post-Feminist Self: Girls' Video Production and YouTube, In: M.C. Kearney, ed., Mediated Girlhoods: New Explorations of Girls' Media Culture. New York: Peter Lang, 277-294.

Blatterer, H., 2015. Everyday Friendships: Intimacy as Freedom in a Complex World [online]. Basingstoke: Palgrave Macmillan. Available from: https://doi.org/10.1057/9781137316400 [Accessed 12 September 2019].

Blatterer, H., and Magaraggia, S., 2016, Introduction, In: F. Alberoni, Friendship. Leiden/Boston, MA: Brill, 1-15.

Bracciale, R., 2010. Donne nella rete: Disuguaglianze digitali di genere. Milan: Franco Angeli. 
Budgeon, S., 2001. Emergent Feminist(?) Identities Young Women and the Practice of Micropolitics. European Journal of Women's Studies [online], 8(1), 7-28. Available from: https://doi.org/10.1177\%2F135050680100800102 [Accessed 12 September 2019].

Butler, J., 1988. Performative Acts and Gender Constitution: An Essay in Phenomenology and Feminist Theory. Theatre Journal [online], 40(4), 519-531. Available from: https://doi.org/10.2307/3207893 [Accessed 12 September 2019].

Cassell, J., and Cramer, M., 2008, High Tech or High Risk? Moral Panics about Girls Online. In: T. McPherson, ed., Digital Youth, Innovation, and the Unexpected. Cambridge, MA: The MIT Press, 53-75.

Cockburn, C., and Ormrod, S., 1993. Gender and Technology in the Making. London: Sage.

Dobson, A.S., 2015. Postfeminist Digital Cultures: Femininity, Social Media, and SelfRepresentation. New York: Palgrave Macmillan.

Earl, J., et al., 2015. New technologies and social movements. In: D. della Porta and M. Diani, eds., The Oxford Handbook of Social Movements. Oxford University Press.

Gajjala, R., and Oh, Y.J., 2012. Cyberfeminism 2.0. New York: Peter Lang.

Gill, R.C., 2007. Critical Respect: The Difficulties and Dilemmas of Agency and "Choice" for Feminism. European Journal of Women's Studies [online], 14(1), 69-80. Available from: https://doi.org/10.1177\%2F1350506807072318 [Accessed 12 September 2019].

Hajek, A., 2018. Je ne suis pas Catherine Deneuve: Reflections on contemporary debates about sexual self-determination in Italy. Modern Italy [online], 23(2), 139143. Available from: https://doi.org/10.1017/mit.2018.10 [Accessed 12 September 2019].

Harris, A., 2008. Young Women, Late Modern Politics, and the Participatory Possibilities of Online Cultures. Journal of Youth Studies [online], 11(5), 481-495. Available from: https://doi.org/10.1080/13676260802282950 [Accessed 12 September 2019].

Harris, A., and Dobson, A.S., 2015. Theorizing Agency in Post-Girlpower Times. Continuum: Journal of Media \& Cultural Studies [online], 29(2), 1-12. Available from: https://doi.org/10.1080/10304312.2015.1022955 [Accessed 12 September 2019].

Magaraggia, S., and Ruspini, E., 2017, Contemporary Net-Activism: beyond Gender Dichotomies? In: F. Antonelli, ed., Net-Activism: How Digital Technologies Have Been Changing Individual and Collective Action [online], 61-67. Available from: http://romatrepress.uniroma3.it/ojs/index.php/net/article/download/688/684 [Accessed 12 September 2019].

Mainardi, A., 2018. “The pictures I really dislike are those where the girls are naked!": Postfeminist norms of female sexual embodiment in contemporary Italian digital culture. Modern Italy [online], 23(2), 187-200. Available from: https://doi.org/10.1017/mit.2018.6 [Accessed 12 September 2019]. 
Mattoni, A., and Treré, E., 2014, Media Practices, Mediation Processes, and

Mediatization in the Study of Social Movements. Communication Theory [online], 24(3), 252-271. Available from: https://doi.org/10.1111/comt.12038 [Accessed 12 September 2019].

Mazzarella, S.R., ed., 2010. Girl Wide Web 2.0: Revisiting Girls, the Internet, and the Negotiation of Identity. New York: Peter Lang.

McRobbie, A., 2009. The Aftermath of Feminism: Gender, Culture and Social Change. London: Sage.

Mitchell, C., and Reid-Walsh, J., 2008. Girl Method: Placing Girl-centred Research Methodologies on the Map of Girlhood Studies. In: J. Klaenn, ed., Roadblocks to Equality: Women Challenging Boundaries. Montreal: Black Rose Books, 214-233.

Pavan, E., 2017, The integrative Power of Online Collective Action Networks Beyond Protest. Exploring Social Media Use in the Process of Institutionalization. Social Movement Studies [online], 16(4), 433-446. Available from: https://doi.org/10.1080/14742837.2016.1268956 [Accessed 12 September 2019].

Pavan, E., and Mainardi, A., 2019. At the roots of media cultures. Social movements producing knowledge about media as discriminatory workspaces. Information, Communication and Society [online], 1-17. Available from:

https://doi.org/10.1080/1369118X.2019.1631372 [Accessed 12 September 2019].

Ringrose, J., 2011. Are You Sexy, flirty, or a Slut? Exploring “Sexualization" and How Teen Girls Perform/Negotiate Digital Sexual Identity on Social Networking Sites. In: R. Gill and C. Scharff, eds., New Femininities: Postfeminism, Neoliberalism and Subjectivity [online]. London: Palgrave Macmillan, 99-116. Available from: https://doi.org/10.1057/9780230294523 7 [Accessed 12 September 2019].

Ringrose, J., and Barajas, K.E., 2011, Gendered Risks and Opportunities? Exploring Teen girls' Digitized Sexual Identities in Postfeminist Media Contexts. International Journal of Media and Cultural Politics [online], 7(2), 121-138. Available from: https://doi.org/10.1386/macp.7.2.121_1 [Accessed 12 September 2019].

Ringrose, J., et al., 2013, Teen Girls, Sexual Double Standards and "Sexting": Gendered Value in Digital Image Exchange. Feminist Theory [online], 14(3), 305-323.

Available from: https://doi.org/10.1177\%2F1464700113499853 [Accessed 12 September 2019].

Stacey, J., 1990, Sexism by a Subtler Name? Poststructural Conditions and Post-feminist Consciousness in Silicon Valley. In: K.V., Hansen and I.J. Philipson, eds., Women, Class, and the Feminist Imagination: A Socialist Feminist Reader. Philadelphia: Temple University Press, 338-356.

Tiqqun, 2001. Raw Materials for a Theory of the Young-Girl. Paris: Mille Et Une Nuits. van Zoonen, L., 2013. From Identity to Identification: Fixating the Fragmented Self. Media, Culture \& Society [online], 35(1), 44-51. Available from: https://doi.org/10.1177\%2F0163443712464557 [Accessed 12 September 2019]. 
Wajcman, J., 2009. Feminist Theories of Technology. Cambridge Journal of Economics [online], 34(1), 143-52. Available from: https://doi.org/10.1093/cje/ben057 [Accessed 12 September 2019].

Wilding, F., 1998, Notes on the Political Condition of Cyberfeminism. Art Journal [online], 57(2), 47-59. Available from: https://doi.org/10.1080/00043249.1998.10791878 [Accessed 12 September 2019].

Zappino, F., ed., 2016. Il genere tra Neoliberismo e Neofondamentalismo. Verona: Ombre Corte. 